\title{
OBSERVATIONS RELATING TO THE ETIOLOGY OF PATENT DUCTUS ARTERIOSUS
}

\author{
BY \\ R. G. RECORD AND THOMAS MCKEOWN \\ From the Department of Social Medicine, University of Birmingham \\ Received June 25, 1953
}

In a recent investigation of 633 cases of congenital heart disease it was noted that the incidence of patent ductus arteriosus appeared to be higher in first-born than in later-born (MacMahon, 1952). The number of affected (48) was rather small, however, and it seemed important to confirm the observation on a larger series. In the present communication data are recorded on 166 cases of patent ductus arteriosus; it is shown that affected boys are more common among first-born than among later-born, and affected girls are more common among children of young mothers than of older mothers. In view of the association of incidence with maternal age and birth order we have looked for other evidence of environmental influence, and it is noted that $(a)$ there is a marked seasonal fluctuation in the number of affected girls (but not of boys), and $(b)$ a history of fœtal distress at birth was recorded in a considerable proportion of cases. The possible significance of the last observation is discussed in relation to experimental work on the mechanism of closure of the ductus.

\section{Material AND Methods}

The series of 166 cases was assembled from children born in the Birmingham hospital region in the period 1936 to 1952.

(a) Forty-eight cases born to Birmingham mothers in the years 1940-49 and included in the earlier series (MacMahon et al., 1953),

(b) Eleven cases born to Birmingham mothers in the years 1940-49, and not included in the earlier series,

(c) Fourteen cases born to Birmingham mothers in the years 1936-39 and 1950-52,

(d) Forty-eight cases born outside Birmingham in the period 1936-52, but treated in Birmingham hospitals, and

(e) Forty-five cases born and treated outside Birmingham.

Excluded from the series (except in Table IV) are 16 infants who died in the neonatal period, for whom the diagnosis was considered unreliable. We have also excluded cases in which there was another defect of the heart or great vessels, on the grounds that persistent patency of the ductus may have been secondary to the other lesion.

Among the 121 cases identified by Birmingham pædiatricians and pathologists $[(a)-(d)$ above] the diagnosis was confirmed at operation in 79 and at autopsy in 19 . In the remaining 23 cases the diagnosis rested on clinical examination and the results of special investigations. Details of the $\mathbf{4 5}$ cases born and treated outside Birmingham were provided by pædiatricians practising in the Birmingham region, but did not include the methods by which the diagnosis was established.

Mothers living within 10 miles of Birmingham were visited and a history recorded which included the date of birth of the mother, the date and place of birth and birth rank of the patient, and details of the related pregnancy and labour. The same data were obtained by writing to the 52 mothers living more than 10 miles from Birmingham. For 37 children born in hospital we were able to obtain more reliable information about pregnancy and birth by inspection of the hospital delivery notes. 
The examination of maternal age and birth rank relies on a comparison of the affected with the population of births from which they are drawn. The distribution of this population by maternal age and birth rank is estimated from a sample of 1015 Birmingham births (see MacMahon, 1952) and from data for the Region Midland I (1940-49) published in the Registrar-General's Statistical Reviews for England and Wales (Part II, civil). The proportion of Birmingham births among affected is $\mathbf{4 4}$ per cent, and the RegistrarGeneral's data for the Region have therefore been weighted in relation to the sample to give roughly the same proportion of Birmingham births in the controls.

\section{InCidence Related to Birth Rank and Maternal Age}

Table I gives the distribution by birth rank and maternal age of 152 affected (48 males and 104 females), and the percentage distribution of controls. The proportion in the first birth rank is higher for affected $(53.9 \%)$ than for controls $(39.8 \%)$ as are also the proportions at low maternal ages. The results are confirmed in Table II, which compares the numbers of cases observed at birth ranks 1 (82) and 2 and over (70), with the numbers expected (61 and 91 respectively) on the assumption that affected are distributed in the same proportions as controls. The same treatment is used in Table III to show that the number of patients born to mothers under 25 (57) is higher than the number expected (42) if incidence were unrelated to maternal age.

TABLE I

152 Cases of Patent Ductus Arteriosus distributed according to Birth Rank and Age of Mother

\begin{tabular}{|c|c|c|c|c|c|c|c|c|}
\hline Maternal age & \multicolumn{5}{|c|}{ Birth rank } & \multirow{2}{*}{$\begin{array}{l}\text { All birth } \\
\text { ranks }\end{array}$} & \multirow{2}{*}{$\begin{array}{c}\text { Both sexes } \\
\text { (percentage) }\end{array}$} & \multirow{2}{*}{$\begin{array}{c}\text { Controls } \\
\text { (percentage) }\end{array}$} \\
\hline & 1 & 2 & 3 & 4 & 5 and over & & & \\
\hline $\begin{array}{ll}\text { Under } 20 & . \\
20-24 . . & . \\
25-29 . . & . \\
30-34 . . & . \\
35-39 . . & . \\
40 \text { and over } & . \\
\text { All ages } & .\end{array}$ & $\begin{array}{rr}M & F \\
4 & 3 \\
9 & 27 \\
12 & 14 \\
5 & 4 \\
1 & 1 \\
\frac{1}{31} & 2\end{array}$ & $\begin{array}{cr}M & F \\
- & 2 \\
-4 & 10 \\
4 & 5 \\
= & 1 \\
8 & 27\end{array}$ & $\begin{array}{cc}M & F \\
& \frac{1}{2} \\
\frac{2}{2} & 4 \\
\frac{2}{5} & 6 \\
& 14\end{array}$ & $\begin{array}{l}M \quad F \\
=\frac{F}{二} \\
=\quad 2 \\
=\quad 1 \\
=\quad 7\end{array}$ & $\begin{array}{ll}M & F \\
- & \frac{F}{7} \\
1 & 3 \\
2 & \frac{1}{1} \\
4 & 5\end{array}$ & $\begin{array}{rr}M & F \\
4 & 5 \\
10 & 38 \\
16 & 28 \\
12 & 18 \\
5 & 11 \\
1 & 4 \\
48 & 104\end{array}$ & $\begin{array}{r}5 \cdot 9 \\
31 \cdot 6 \\
28 \cdot 9 \\
19 \cdot 7 \\
10 \cdot 5 \\
3 \cdot 3 \\
-\end{array}$ & $\begin{array}{r}3 \cdot 0 \\
24 \cdot 8 \\
30 \cdot 8 \\
22 \cdot 8 \\
13 \cdot 8 \\
4 \cdot 8 \\
-\end{array}$ \\
\hline $\begin{array}{l}\text { Both sexes } \\
\text { Controls }\end{array}$ & $\begin{array}{l}53.9 \% \\
39 \cdot 8 \%\end{array}$ & $\begin{array}{l}23.0 \% \\
29.0 \%\end{array}$ & $\begin{array}{l}12.5 \% \\
14.0 \%\end{array}$ & $\begin{array}{l}4 \cdot 6 \% \\
7 \cdot 4 \%\end{array}$ & $\begin{array}{l}5.9 \% \\
9.8 \%\end{array}$ & 二 & 100 & $\overline{100}$ \\
\hline
\end{tabular}

Because of the high correlation between maternal age and birth rank ( $r$ is approximately $0 \cdot 5)$ it is desirable to separate the effects of these two variables. The method employed for this purpose is essentially a process of standardization which uses the percentage distribution of controls to give the numbers of affected expected: $(a)$ in each birth rank and maternal age group (Tables II and III); $(b)$ in each birth rank when the influence of maternal age is removed (Table II); and $(c)$ in each maternal age group when the influence of birth rank is removed (Table III). It is shown that the association of incidence with primogeniture is independent of maternal age, but the association with age is negligible when the influence of birth rank is removed.

The same methods are used to examine separately for males and females the association of incidence with the two variables. The proportion of males in the first birth rank is substantially raised, and this result is independent of maternal age (Table II); indeed the incidence of males appears to be unrelated to age (Table III). On the other hand, the incidence of affected females is unrelated to birth rank (Table II), but is raised at maternal ages under 25. A possible, if not a probable, explanation of this sex difference is referred to below under the discussion of sex ratios. 
TABLE II

Association of InCIDENCE With BirTh RanK

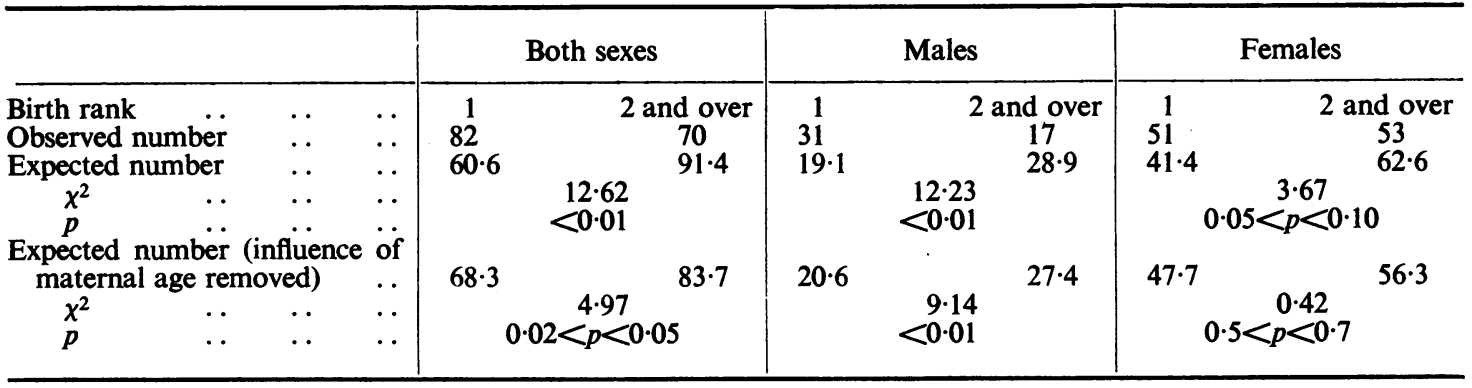

TABLE III

AsSociation of INCIDENCE WITH Age OF MOTHER

\begin{tabular}{|c|c|c|c|c|c|c|c|}
\hline \multirow[b]{2}{*}{$\begin{array}{l}\text { Maternal age } \\
\text { Observed number } \\
\text { Expected number }\end{array}$} & & \multicolumn{2}{|c|}{ Both sexes } & \multicolumn{2}{|c|}{ Males } & \multicolumn{2}{|c|}{ Females } \\
\hline & $\begin{array}{ll}. & . \\
\because & .\end{array}$ & $\begin{array}{l}\text { Under } 25 \\
57 \\
42 \cdot 3\end{array}$ & $\begin{array}{c}25 \text { and over } \\
95 \\
109 \cdot 7\end{array}$ & $\begin{array}{l}\text { Under } 25 \\
14 \\
13.4\end{array}$ & $\begin{array}{c}25 \text { and over } \\
34 \\
34 \cdot 7\end{array}$ & $\begin{array}{l}\text { Under } 25 \\
43 \\
28 \cdot 9\end{array}$ & $\begin{array}{c}25 \text { and over } \\
61 \\
75 \cdot 1\end{array}$ \\
\hline $\begin{array}{cc}\chi^{2} & . \\
p & \ddot{ }\end{array}$ & $\begin{array}{l}\because \\
\text { guence }\end{array}$ & \multicolumn{2}{|c|}{$\begin{array}{r}72.3 \\
<0.09\end{array}$} & \multicolumn{2}{|c|}{$0.8<p<0.9$} & \multicolumn{2}{|c|}{$\begin{array}{r}9.48 \\
<0.01\end{array}$} \\
\hline \multicolumn{2}{|c|}{$\begin{array}{c}\text { Expected number (influence of } \\
\text { birth rank removed) }\end{array}$} & \multirow{2}{*}{\multicolumn{2}{|c|}{$\begin{array}{lll}50.2 & 1.39 & 101 \cdot 8\end{array}$}} & \multirow{2}{*}{$\begin{array}{r}17 \cdot 4 \\
0 \cdot 3\end{array}$} & $30 \cdot 6$ & $32 \cdot 7$ & $71 \cdot 3$ \\
\hline $\begin{array}{ll}\chi^{2} & \cdots \\
p & \cdots\end{array}$ & $\begin{array}{ll}. & . \\
. & .\end{array}$ & & $39<0.3$ & & $5<0.5$ & \multicolumn{2}{|c|}{$0.02<p<0.05$} \\
\hline
\end{tabular}

\section{The Condition of THe Child AT BiRTH}

Since we have no reason to suppose that variation associated with maternal age and birth order is determined genetically, the observations recorded above must be attributed to environment. This prompts consideration of the kind of influence that might be expected to be related to the ætiology of patent ductus arteriosus, and to operate more frequently in first-born and at low maternal ages. A possibility that seemed worth exploring was suggested by Kennedy's proposal (1942) that uncomplicated persistent patency of the ductus should not be regarded as a malformation, but should be attributed to defective oxygenation of the blood during birth or shortly after. Since difficulties of labour are undoubtedly more common in first-born, it seemed reasonable to enquire whether there was evidence of fotal distress during delivery of affected patients.

Place of birth was known in 150 cases. Unfortunately we have been able to examine notes recorded at delivery for only 37 hospital births; in $16(43 \%)$ there was a history of fotal distress. For the remaining 15 hospital births whose records were lost, and for 98 domiciliary and nursinghome births, we have had to rely on mothers' statements, according to which $4(27 \%)$ and $22(22 \%)$ of the infants in the two groups respectively showed signs of distress at birth. Brief details of the observations accepted as evidence of fotal distress were given in an appendix, but have been omitted to save space. Shortly, representative notes were as follows: toxæmia and blue asphyxia; long labour and fotal distress; thirty-six hour labour and pneumonia on the third day; fotal distress in second stage, cord obstructed and infant very shocked; white asphyxia and much inhaled mucus; blue asphyxia and cord round neck; not expected to live; forceps delivery and pneumonia at two days; and breech delivery and blue at birth.

Although the information taken from hospital notes can be regarded as reliable, it is evident that the mother's knowledge of the circumstances at birth must be interpreted with some reserve. Nevertheless some of the details are of a kind about which it is hard to believe that a mother could be mistaken (administration of oxygen, pneumonia, a child not expected to live), 
and having regard for the higher incidence of complications in cases in which notes were inspected, it seems likely that the mother's history understates the frequency of complications. But whether we consider 43 or 28 per cent as the more acceptable figure, it can hardly be doubted that the proportion of infants with a history of distress is very much higher than would be expected among normal births. Lund (1941) noted that the proportion of infants who did not breathe within one minute of birth and cry lustily soon after was 15 per cent; Keith and Norval (1950) gave 5 per cent as the frequency of asphyxia and delayed respiration.

In seeking an explanation for the high incidence of fœtal distress in cases of patent ductus arteriosus, we may examine first the possibility that asphyxia is secondary to the abnormality. Since the ductus normally remains open for the first few minutes of extra-uterine life (Kennedy and Clark, 1941; Barclay et al., 1944; Lind and Wegelius, 1952) this explanation is obviously unacceptable. It also would not account for cyanosis shortly after birth, for in the absence of other cardiovascular defect or obstruction to the circulation in the lungs, the direction of blood flow through the ductus is from left to right. It seems unlikely therefore that these cases of fotal distress, asphyxia, or cyanosis can be ascribed to patency.

Before considering the possibility that the abnormality may sometimes be secondary to difficulties at birth, it may be helpful to summarize briefly the results of experimental work on the mechanism of closure. At the outset it is necessary to distinguish between functional closure, which is effected rapidly after birth (in man: Keith and Forsyth, 1950; Lind and Wegelius, 1952; in the guinea-pig: Kennedy and Clark, 1941; in sheep: Barclay et al., 1944; in dogs, Everett and Johnson, 1951), and anatomical obliteration of the lumen, which may not be complete for some weeks (Christie, 1930; Jager and Wollenman, 1942). This distinction was clearly recognized by Gerard (1900), and Wells (1908) stated that functional closure of the ductus " is a physiological process taking place simultaneously and instantaneously in every new-born child, and therefore there must be some mechanism which can be relied upon always to perform this occlusion. Any explanation that involves connective tissue proliferation must be inadequate, for the duct is patent and then is at once occluded when the child begins to breathe; it is necessary to distinguish between the instantaneous occlusion of the duct and its subsequent obliteration."

Hamilton et al. (1937) showed that in dog and rabbit foetuses inspiration lowered the pressure in the right ventricle, and they considered that in these species the tendency to reversal of blood flow through the ductus is prevented by a flap-like valve at the aortic end. There is no structure of this type in the human foetus, and Barclay et al. (1944) found no evidence of a valve in the guinea-pig, or in a moribund lamb examined by cineradiography.

Perhaps the most significant observations in the present context are those of Kennedy and Clark (1942) on the guinea-pig. They noted that artificial ventilation of the lungs with nitrogen did not cause closure; but ventilation with an oxygen-containing mixture, or intravenous injection of oxygen, was followed rapidly by closure of the ductus, and this result was repeated after section of all known nervous connections to the heart. They concluded that under normal physiological conditions respiration is the most important stimulus to closure.

Barron (1944) was unable wholly to accept this chemical explanation of the mechanism, and drew attention to the fact that the ductus remains open during foetal life, although the percentage of saturation of oxygen in the blood may be high: "In utero the ductus is open, and it certainly is closed in lambs before the oxygen content of their blood returns to the intra-uterine level." But data published by Barcroft $e t$ al. (1940a) do not support this view: in sheep the oxygen saturation of carotid blood varied between 37 and 52 per cent during the last week of gestation, and rose within a few minutes after birth (Barcroft $e$ t al. 1939). The high values referred to by Barron were recorded by Barcroft $e t$ al. (1940b) some weeks before term, and it may be questioned whether it is reasonable to base an opinion about the mechanism of closure after birth on observations at this time. Barron's own report (1944) that perfusion of the foetal lamb with oxygen saturated blood did not lead to closure is hardly convincing, since formalin injected to fix the tissues may have caused relaxation of the ductus-a point made in another context by Barcroft (1946).

A more serious objection to the chemical explanation of the mechanism is provided by a single case recorded by Ardran et al. (1952) who used cine-angiography to demonstrate constriction of the duct after 21 seconds, and closure after a further 64 seconds and before ventilation of the lungs, in a lamb whose umbilical cord had been tied. On the other hand Ekström (1952) reported that Johnsson had shown by angiocardiography a widely patent ductus with right to left circulation in a cyanosed new-born infant: a 
week later when the cyanosis had disappeared the ductus was found to be closed. Lind and Wegelius (1952) also used angiocardiography to show patency of the ductus with right to left blood-flow in two asphyxiated new-born infants.

There is thus a good deal of evidence that asphyxia at birth may delay closure of the ductus. But it is not easy to see why persistent patency should result from a condition that is apparently so transient. We can offer no explanation, although we may note that the respiratory embarrassment of the fotus may not always be so transient as it appears. Intra-uterine anoxia may stimulate the fœetus, and cause it to inspire amniotic fluid containing epithelial cells and vernix which become trapped in the alveolar ducts (Wilson and Farber, 1933; Potter, 1952). Farber and Sweet (1931) found large quantities of cornified cells and vernix in the lungs of 15 per cent of infants who died between two hours and five weeks after birth. This suggests that the results of severe pre-natal anoxia may affect the lungs for a protracted period until the vernix has been absorbed; respiratory exchange may be limited further by the presence of micro-organisms. In this context it is interesting to note that of the $\mathbf{4 4}$ cases of fotal distress listed in the appendix, one had bronchitis at birth, and three others had pneumonia at the second or third day. These observations merely remind us that respiratory embarrassment may commonly last for days rather than minutes; they do not dispose of the objection that closure might be expected to follow relief of the embarrassment unless the possibility of closure is limited to a short period after birth. So far as we are aware there is no direct evidence on this point. It has been shown in Fallot's tetralogy that even in the presence of anoxia the ductus may be obliterated many months after birth, but it is not certain that this observation has much bearing on the normal mechanism of closure.

\section{SEASONAL INCIDENCE}

Rutstein et al. (1952) examined the seasonal incidence of 254 cases of patent ductus arteriosus in Massachusetts, and found a low incidence from February to August, and a high incidence from October to January. We have compared the monthly distribution of these cases with that of 162 affected from the Birmingham region. (We are able to compare the actual numbers, because there are only small seasonal fluctuations in the numbers of related births.) The two distributions are quite different, incidence in Birmingham being highest from May to December and lowest from January to April.

An interesting feature of the seasonal incidence is exhibited by separate examination of the two sexes (Fig. 1). With the exception of a small increase during November and December, the number

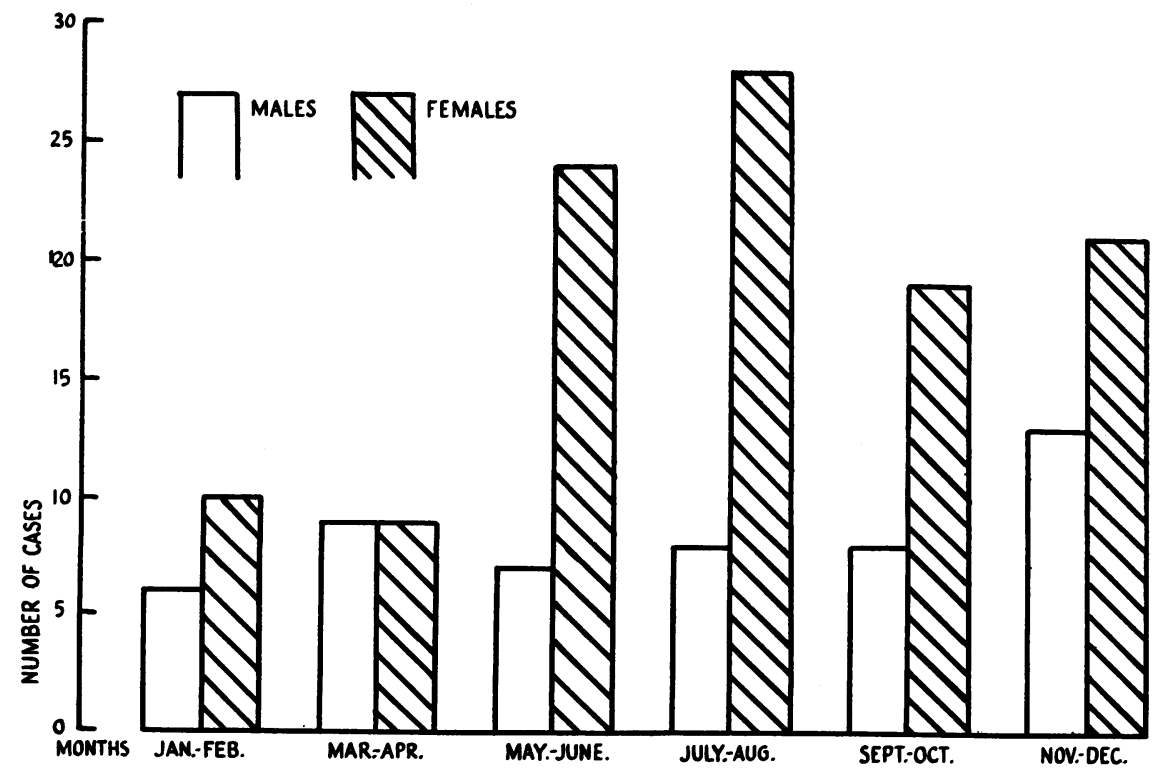

Fig. 1.-Seasonal incidence of the time of birth of patients with patent ductus arteriosus. 
of affected males is fairly constant throughout the year. The seasonal variation is due to a marked seasonal fluctuation in the number of females, which is only slightly greater than that of males during the first four months of the year, but rises greatly during the summer months (May to August) and remains relatively high during the rest of the year. This results, as would be expected, in marked seasonal variation in the sex ratio of affected: the proportion of males fluctuates between 22 (July-August) and 50 per cent (March-April).

Rutstein et al. (1952) showed that the seasonal incidence of their cases corresponded roughly with that of rubella notifications in Massachusetts seven months earlier. Fig. 2 shows a similar comparison between Birmingham cases of patent ductus arteriosus and rubella notifications in Manchester (1936-51: war years excluded). Rubella is not notified in Birmingham, but it seems unlikely that its seasonal incidence would differ appreciably from that in Manchester, an industrial city of approximately the same size less than 100 miles away. The two distributions are entirely different and give no grounds for the view that the seasonal fluctuation in the number of affected could be attributed to rubella.

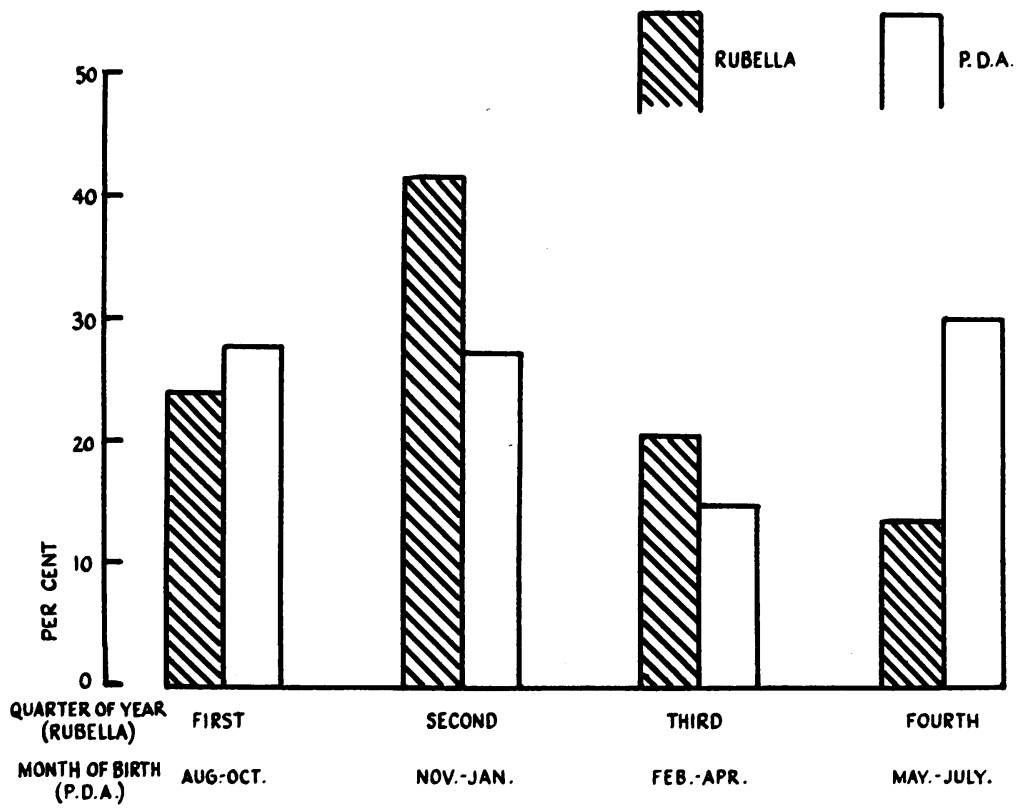

FIG. 2.-Seasonal incidence of patent ductus arteriosus (Birmingham Region, 1936-52 compared with rubella notifications in Manchester (1936-51).

A reasonably satisfactory history of the pregnancy was obtained for 150 cases, which included three with abnormalities involving the special senses (blindness in one, and deafness in two). A history of rubella during the first three months of pregnancy was elicited in two of these three cases, and in only one of the remaining 147 cases. Although the results of retrospective enquiry on a matter of this kind must be treated with reserve, the difference between the two groups is impressive: it gives some grounds for the belief that $(a)$ a history of rubella can often be elicited if it is present, and $(b)$ rubella is not commonly related to the ætiology of patent ductus (a conclusion in accord with results published by Dogramaci and Green, 1947, and Lynxwiler and Wells, 1950), unless the defect is associated with other abnormalities. It is possible that by confining attention to cases uncomplicated by other cardiovascular defects we have reduced the apparent significance of rubella, since Gibson and Lewis (1952) suggested that a history of rubella is relatively more common in cases of patent ductus arteriosus associated with other heart lesions. 


\section{Sex Ratio}

It is generally believed that the sex ratio in patent ductus arteriosus (expressed as the percentage of males among affected) is about 30 per cent (Abbott, 1936; Gilchrist, 1945; Brown, 1950). Of the 166 cases included in the present series, $51(30.7 \%)$ were males. We have, however, excluded 16 neonatal deaths, and when these are included the sex ratio is a little higher $(34 \%)$.

Table IV shows that the proportion of affected which are males is related to the time at which cases are observed, being 29 per cent in patients alive at one year, 44 per cent in patients who died between 1 and 12 months, and 62 per cent in neonatal deaths. The same association between sex ratio and the age of patients on whom the observations are made is also evident in 244 reported

TABLE IV

Sex Ratio according to Age

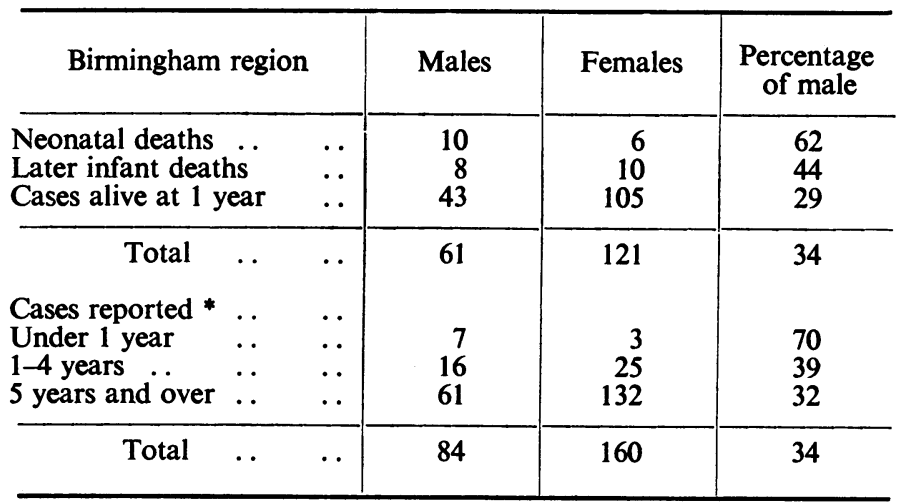

* Derived from 14 papers (indicated in the list of references by asterisks).

cases (Table IV). It is clear therefore that the proportion of males among all children affected is higher than most estimates suggest, and if the number of undiagnosed early deaths is relatively large, it is not impossible that numbers of the two sexes affected at birth are nearly equal.

The higher early mortality in males suggests a possible, though perhaps not a probable explanation of the difference between males and females in the association of incidence with maternal age and birth order (Tables II and III). This difference is exhibited in another way in Table V. The percentage of males is highest $(46 \%)$ in first children of women aged 25 and over, and lowest $(7 \%)$ in later children of women under 25. These differences suggest the possibility that the proportion of males among cases of patent ductus arteriosus is related to social circumstances, since first births at high maternal ages, and later births at low maternal ages, are characteristic of favourable and unfavourable social circumstances respectively. This point is demonstrated in Table VI, in which Scottish data are used to give the proportion of births in social classes

TABLE V

Sex Ratios ACCORDING to Birth RaNK

\begin{tabular}{l|l|r|r|r}
\hline \multirow{2}{*}{ Maternal age } & & \multicolumn{3}{|c}{ Birth rank } \\
\cline { 2 - 4 } & & 1 & 2 & 3 and over \\
\hline Under 25 & Males & 13 & 1 & \\
& Females & 30 & 13 & \\
& Percentage of males & 30 & 7 & 8 \\
& Males & 18 & 8 & 25 \\
& Females & 21 & 15 & 24 \\
\hline
\end{tabular}


I and II (the most favourably placed) according to birth rank and maternal age. Since early mortality is higher in males than in females, it is conceivable that the association between sex and maternal age and birth order in patent ductus arteriosus might be explained by assuming that mortality is related to social circumstances, by no means an unreasonable assumption. In this case a lower mortality in males (and hence a higher percentage of males among surviving cases) would be expected in first births at high maternal ages, and a higher male mortality (and a lower percentage of surviving males) in later births at low ages. Whatever the degree of credibility which this explanation merits, it at least reminds us of the kind of interpretation we should have in mind when considering the association of incidence with maternal age and birth rank.

TABLE VI

Distribution of Births (Live and Still-born) according to Social Class of Father. (Scotland, 1950)

\begin{tabular}{|c|c|c|c|c|c|}
\hline \multirow{2}{*}{ Maternal age } & \multirow{2}{*}{ Social class } & \multicolumn{3}{|c|}{ Birth rate } & \multirow{2}{*}{ Total } \\
\hline & & 1 & 2 & 3 and over & \\
\hline Under 25 & $\begin{array}{l}\text { (a) I and II } \\
\text { (b) III, IV and V } \\
(a) \text { as percentage of }(a)+(b)\end{array}$ & $\begin{array}{r}1,520 \\
15,041 \\
9 \cdot 2\end{array}$ & $\begin{array}{c}531 \\
6,868 \\
7 \cdot 2\end{array}$ & $\begin{array}{c}144 \\
2,806 \\
4 \cdot 9\end{array}$ & $\begin{array}{r}2,195 \\
24,715 \\
8 \cdot 2\end{array}$ \\
\hline \multirow[t]{2}{*}{25 and over } & $\begin{array}{l}\text { (a) I and II } \\
\text { (b) III, IV and V } \\
(a) \text { as percentage of }(a)+(b)\end{array}$ & $\begin{array}{c}3,572 \\
11,878 \\
23 \cdot 1\end{array}$ & $\begin{array}{c}3,796 \\
14,493 \\
20 \cdot 8\end{array}$ & $\begin{array}{c}3,631 \\
25,600 \\
12 \cdot 4\end{array}$ & $\begin{array}{l}10,999 \\
51,971 \\
17 \cdot 5\end{array}$ \\
\hline & \multicolumn{5}{|c|}{ Derived from data in the Annual Report of the Registrar-General for Scotland, 1950.} \\
\hline
\end{tabular}

\section{FAMILIAL INCIDENCE}

(a) Sibs. A reasonably satisfactory family history was obtained for 150 fraternities containing propositi with patent ductus arteriosus; Table VII gives details of the 7 fraternities in each of which another sib was said to have some form of congenital heart disease. The diagnosis was confirmed at operation or autopsy in 4 of the 7 sibs; in only one fraternity is it certain that the second child also had patent ductus arteriosus.

The incidence of malformation in sibs born before propositi is of little interest (because they are unrepresentative), and we confine attention to 124 live-born sibs born after propositi, of which 3 certainly had congenital heart disease, and one was possibly affected. The corresponding figures for incidence in later sibs (per 1000) are therefore 24 and 32 respectively, appreciably higher than the incidence in the general population of births (3.2 per 1000), but perhaps not significantly higher than in sibs of children exhibiting all types of congenital heart malformation (18 per 1000: McKeown, MacMahon and Parsons, 1953).

Examination of the literature since 1930 gave details of 11 fraternities with two or more cases of patent ductus arteriosus in which the diagnosis appeared to be reliable (Ellis, 1932; Snelling, 1937; Brown, 1939; Stein and Barber, 1945; Kjaergaard, 1946; and Ekström (6 examples), 1952). By including our own fraternity we have obtained information about the sex of 26 patients in fraternities with at least 2 members affected: 3 are males, and 23 females. It can readily be shown that this unusual sex ratio is unlikely to have arisen by chance.

Assuming a sex ratio of 30 per cent male, and considering families containing two affected individuals, the chance of both patients being female is $(0 \cdot 7)^{2}$ or roughly $\frac{1}{2}$. The chance that in 10 such fraternities both affected will be female in at least 7 is given by summing the first four terms of the expansion of the binomial $\left(\frac{1}{2}+\frac{1}{2}\right)^{10}$, which gives a probability of $0 \cdot 172$. Considering families containing three affected individuals, the chance of all three being female is $(0 \cdot 7)^{3}$, and the chance that two such fraternities will each contain females is therefore $\left[0.7^{3}\right]^{2}$ or $0 \cdot 118$. The combined chance of all the affected being female in at least 7 of 10 fraternities containing two patients and in two fraternities containing three patients is $0.172 \times 0.118$ or 0.02 . The observed sex ratio in sibships with more than one affected is therefore unlikely to have arisen by chance, 
TABLE VII

Details of 7 Fraternities in which a Sib had Congenital Heart Disease

\begin{tabular}{|c|c|c|c|}
\hline Birth rank & Sex & Fate & Diagnosis \\
\hline$\frac{1}{2}$ & $\begin{array}{l}\mathbf{F} \\
\mathbf{M}\end{array}$ & $\begin{array}{l}\text { Alive at } 23 \text { years } \\
\text { Alive at } 21 \text { years }\end{array}$ & $\begin{array}{l}\text { Congenital heart disease-type not certainly known but not patent } \\
\text { ductus arteriosus (clinical examination) }\end{array}$ \\
\hline $\begin{array}{l}3 \\
4\end{array}$ & $\begin{array}{l}F^{*} \\
F\end{array}$ & $\begin{array}{l}\text { Alive at } 16 \text { years } \\
\text { Alive at } 9 \text { years }\end{array}$ & Patent ductus arteriosus (operation) \\
\hline $\begin{array}{l}1 \\
2 \\
3 \\
4 \\
5\end{array}$ & $\begin{array}{l}\mathbf{M} \\
\mathbf{M} \\
\mathbf{M} \\
\mathrm{F}^{*} \\
\mathbf{F}\end{array}$ & $\begin{array}{l}\text { Alive at } 19 \text { years } \\
\text { Alive at } 16 \text { years } \\
\text { Alive at } 9 \text { years } \\
\text { Alive at } 4 \text { years } \\
\text { Alive at } 7 \text { months }\end{array}$ & $\begin{array}{l}\text { Patent ductus arteriosus (operation) } \\
\text { Patent ductus arteriosus (operation) }\end{array}$ \\
\hline $\begin{array}{l}1 \\
2\end{array}$ & $\begin{array}{l}\mathbf{M}^{*} \\
\mathbf{F}\end{array}$ & $\begin{array}{l}\text { Alive at } 14 \text { years } \\
\text { Alive at } 10 \text { years }\end{array}$ & $\begin{array}{l}\text { Patent ductus arteriosus (operation) } \\
\text { Pulmonary stenosis (operation) }\end{array}$ \\
\hline $\begin{array}{l}1 \\
2 \\
3 \\
4 \\
5 \\
6 \\
7 \\
8\end{array}$ & $\begin{array}{l}\mathbf{F}^{*} \\
\mathbf{F} \\
\mathbf{F} \\
\mathbf{M} \\
\mathbf{M} \\
\mathbf{F} \\
\mathbf{F} \\
\mathbf{F}\end{array}$ & $\begin{array}{l}\text { Died aged } 7 \text { weeks } \\
\text { Alive at } 8 \text { years } \\
\text { Alive at } 7 \text { years } \\
\text { Alive at } 6 \text { years } \\
\text { Alive at } 4 \text { years } \\
\text { Died aged } 3 \text { months } \\
\text { Died aged } 2 \text { days } \\
\text { Alive at } 5 \text { weeks }\end{array}$ & $\begin{array}{l}\text { Unspecified cardiac defect (clinical examination) } \\
\text { Cause of death unknown }\end{array}$ \\
\hline $\begin{array}{l}1 \\
2\end{array}$ & $\begin{array}{l}\mathbf{F} \\
\mathbf{F}^{*}\end{array}$ & $\begin{array}{l}\text { Died at } 3 \text { weeks } \\
\text { Alive at } 4 \text { years }\end{array}$ & $\begin{array}{l}\text { Unspecified cardiac defect (clinical examination) } \\
\text { Patent ductus arteriosus (clinical examination) }\end{array}$ \\
\hline $\begin{array}{l}1 \\
2 \\
3\end{array}$ & $\left\{\begin{array}{l}\mathbf{M}^{*} \\
\mathbf{F} \\
\mathbf{M}\end{array}\right.$ & $\begin{array}{l}\text { Alive at } 8 \text { years } \\
\text { Died aged a few hours } \\
\text { Alive at } 6 \text { years } \\
\text { Alive at } 1 \text { year }\end{array}$ & $\begin{array}{l}\text { Patent ductus arteriosus (clinical examination) } \\
\text { Transposition of great vessels and ventricular septal defect (P.M.) }\end{array}$ \\
\hline $\begin{array}{l}1 \\
2 \\
3 \\
3 \\
5\end{array}$ & $\begin{array}{l}\mathrm{F}^{*} \\
\mathbf{M} \\
\stackrel{\mathrm{F}}{\mathrm{F}} \\
\mathrm{F}\end{array}$ & $\begin{array}{l}\text { Alive at } 6 \text { years } \\
\text { Alive at } 4 \text { years } \\
\text { Alive at } 3 \text { years } \\
\text { Alive at } 2 \text { years } \\
\text { Died aged } 3 \text { days }\end{array}$ & $\begin{array}{l}\text { Patent ductus arteriosus (operation) } \\
\text { Single ventricle with truncus arteriosus (P.M.) }\end{array}$ \\
\hline
\end{tabular}

* Propositus.

and suggests the possibility that cases of patent ductus arteriosus recurring in families may differ ætiologically from other cases. Ekström (1952) made the interesting observation that in patients with affected sibs the ductus is shorter and wider than usual.

(b) Parents. Until recently, ascertainment of cases of patent ductus arteriosus was very incomplete, and hence a reliable estimate of incidence in parents cannot be given. In the present series one parent (the mother of a male propositus) was affected; the diagnosis was confirmed at operation. Lamy and Schweisguth (1950) refer to a mother with ventricular septal defect and patent ductus arteriosus, whose daughter also had a patent ductus, and Taussig (1947) reported the condition in a father with two affected children and one affected grandchild. The mother of a case recorded by Starer (1953) was also said to be affected. But so far as we are aware there is only one reported instance in which the diagnosis was confirmed in both parent and child (Walker, 1951).

(c) Twins. One propositus had a still-born twin who was not examined at autopsy; another propositus had a twin of like sex (female) believed to have congenital heart disease, but the child died at 7 months and the diagnosis was not confirmed. Six cases in so-called identical twins have been reported: in two, both members were affected (Smith, 1929; Starer, 1953); in four, only one was affected (McClintock, 1945; Porter, 1947; Wade, 1952; Starer, 1953). Only Wade used special methods to establish the monozygosity of the twin pair. 


\section{SUMMARY}

Data are recorded in 166 cases of patent ductus arteriosus identified in the Birmingham Hospital Region during the period 1936-52.

Information about the population of births from which cases were drawn is used to show that (a) the incidence of affected boys is substantially higher among first-born than among later-born, and this result is independent of maternal age, and $(b)$ the incidence of affected girls is unrelated to birth rank, but is raised in children of mothers under 25.

Place of birth was known in 150 cases. Hospital delivery notes were inspected in 37 , in $16(43 \%)$ of which there was a history of fœtal distress at birth. For the remaining 15 hospital births whose records were lost, and for 98 domiciliary and nursing-home births, we have had to rely on mothers' statements, according to which $4(27 \%)$ and $22(22 \%)$ of the infants in the two groups respectively showed signs of distress at birth. This incidence is substantially higher than would be expected among normal births, and the possible significance of this observation is discussed against the background of experimental work on closure of the ductus.

The number of affected boys is fairly constant throughout the year, but there is a marked seasonal fluctuation in the number of girls, which is only slightly greater than that of boys during the first four months, but rises sharply during the summer (May to August) and remains relatively high during the rest of the year. Hence the proportion of boys fluctuates between 22 (July-August) and 50 per cent (March-April).

This seasonal incidence of patent ductus arteriosus appears to be unrelated to the incidence of rubella. A history of rubella during the early months of pregnancy was elicited in 2 of 3 cases associated with congenital defects of the special senses (blindness in one and deafness in the other), and in only 1 of 147 uncomplicated cases.

Of the 166 cases $51(31 \%)$ were boys. The proportion of boys among affected is related to the time at which cases are observed, being 29 per cent in patients alive at one year, 44 per cent in patients who died between 1 and 12 months, and 62 per cent in neonatal deaths.

There were 3 confirmed and 1 unconfirmed cases of congenital malformation of the heart among 124 sibs born after propositi. This incidence ( 24 or 32 per 1000 according as we include 3 or 4 cases) is appreciably higher than the incidence in the general population of births $(3 \cdot 2$ per 1000$)$ but is perhaps not significantly higher than in later sibs of children exhibiting all types of cardiac malformation (18 per 1000).

In only one fraternity was a second child as well as the propositus shown to have patent ductus arteriosus. Examination of reported cases gave details of 11 other fraternities with two or more members affected. Of the 26 affected children in these 12 fraternities, 3 were boys and 23 girls.

We are indebted to pædiatricians and pathologists of the Birmingham region, and in particular to Dr. C. G. Parsons and Mr. A. L. d'Abreu, for giving us information about their patients. Miss M. S. Gradwell recorded histories in the homes of patients. The research was assisted by a grant from the Birmingham University Students' Social Services Fund.

\section{REFERENCES}

Abbott, M. E. (1936). Atlas of Congenital Cardiac Disease. American Heart Association, New York, p. 61. Ardran, G. N., Dawes, G. S., Prichard, M. M. L., Reynolds, S. R. M., and Wyatt, D. G. (1952). J. Physiol., $118,12$. Barclay, A. E., Franklin, K. J., and Prichard, M. M. L. (1944). The Fatal Circulation. Blackwell, Oxford, p. 141. Barcroft, J. (1946). Researches on Pre-natal Life. Blackwell, Oxford, Vol. 1, p. 241.

—, Barron, D. H., Cowie, A. T., and Forsham, P. H. (1940a). J. Physiol., 97, 338.

—, Kennedy, J. A., and Mason, M. F. (1940b). J. Physiol., 97, 347.

-, Kramer, K., and Millikan, G. A. (1939). J. Physiol., 94, 571.

Barron, D. H. (1944). Physiol. Rev., 24, 277.

Brown, J. W. (1939). Congenital Heart Disease. John Bale, London, p. 91.

(1950). Congenital Heart Disease. Staples Press, London and New York, p. 117.

*Bullock, L. T., Jones, J. C., and Dolley, F. S. (1939). J. Pediat., 15, 786.

Christie, A. (1930). Amer. J. Dis. Child., 40, 323.

Dogramaci, I., and Green, H. (1947). J. Pediat., 30, 295.

2D 
*Donovan, M. S., Neuhauser, E. B. D., and Sosman, M. C. (1943). Amer. J. Roentgenol., 50, 293.

*East, T. (1945). Brit. Heart J., 7, 95.

Ellis, R. W. B. (1932). Proc. roy. Soc. Med., 26, 511.

Ekström, G. (1952). Acta chir. scand., Supp. 169.

Everett, N. B., and Johnson, R. J. (1951). Anat. Rec., 110, 103.

Farber, S., and Sweet, L. K. (1931). Amer. J. Dis. Child., 42, 1372.

Gerard, G. (1900). J. Anat. Paris, 26, 323. Cited by Barcroft, J. (1946).

Gibson, S., and Lewis, K. C. (1952). Amer. J. Dis. Child., 83, 317.

*Gilchrist, A. R. (1945). Brit. Heart J., 7, 1.

Hamilton, W. F., Woodbury, R. A., and Woods, E. B. (1937). Amer. J. Physiol., 119, 206.

*Havel, R. J., and Watkins, E. (1950). Circulation, 2, 536.

*Hertzman, V. O., and Strong, G. F. (1949). Canad. med. Ass. J., 61, 495.

Jager, B. V., and Wollenman, O. J. (1942). Amer. J. Path., 18, 595.

*Johnson, J., Jeffers, W. A., and Margolies, A. (1942). J. thorac. Surg., 11, 347.

*Jones, J. C., Dolley, F. S., and Bullock, L. T. (1940). J. thorac. Surg., 9, 413.

Keith, H. M., and Norval, M. A. (1950). Pediatrics, 6, 229.

${ }^{*}$ Keith, J. D., and Forsyth, C. (1950). Circulation, 2, 907.

Kennedy, J. A. (1942). Amer. J. med. Sci., 204, 570.

- and Clark, S. L. (1941). Anat. Rec., 79, 349.

- - - (1942). Amer. J. Physiol., 136, 140.

Kjaergaard, H. (1946). Acta med. Scand., 125, 339.

Lamy, M., and Schweisguth, O. (1950). Ann. prediat., 174, 65.

Lind, J., and Wegelius, C. (1952). Acta padiat., Stockh., 41, 495.

Lund, C. J. (1941). Amer. J. Obstet. Gynec., $41,934$.

Lynxwiler, C. P., and Wells, C. R. E. (1950). South. med. J., 43, 61.

McClintock, K. (1945). Arch. Dis. Childh., $20,47$.

McKeown, T., MacMahon, B., and Parsons, C. G. (1953). Brit. Heart J., 15, 273.

MacMahon, B. (1952). Brit. J. soc. Med., 6, 178.

McKeown, T., and Record, R. G. (1953). Brit. Heart J., 15, 121.

*Muir, W. C,, and Brown, J. W. (1932). Arch. Dis. Childh., 7, 291.

Porter, W. B. (1947). Amer. J. med. Sci., 213, 178.

Potter, E. L. (1952). Pathology of the Fetus and the Newborn. Year Book Publishers, Chicago, p. 241.

*Ravin, A., and Darley, W. (1950). Ann. intern. Med., 33, 903.

Rutstein, D. D., Nickerson, R. J., and Heald, F. P. (1952). Amer. J. Dis. Child., 84, 199.

*Shallard, B. (1945). Med. J. Australia, 2, 353.

Smith, K. S. (1929). Arch. Dis. Childh., 4, 330.

Snelling, D. B. (1937). J. Amer. med. Ass., 108, 1502.

Starer, F. (1953). Brit. med. J., 1, 971.

Stein, I., and Barber, D. J. (1945). Amer. Heart J., 30, 118.

*Steinberg, M. F., Grishman, A., and Sussman, M. L. (1943). Amer. J. Roentgenol., 50, 306.

Taussig, H. B. (1947). Congenital Malformations of the Heart. The Commonwealth Fund, New York, p. 8.

Wade, G. (1952). Brit. Heart J., 14, 475.

Walker, R. M. (1951). Bristol med.-chir. J., 68, 133.

Wells, H. G. (1908). Amer. J. med. Sci., N.S., 136, 381.

Wilson, J. L., and Farber, S. (1933). Amer. J. Dis. Child., 46, 590.

*Ziegler, R. F. (1952). Amer. Heart J., 43, 553.

* Publications used in compiling Table IV. 